\title{
[第37回総会シンポジゥム]
}

\section{II. 医用X線システムの人間工学的設計}

\author{
座長神田幸助（立正佼成会附属佼正病院） \\ 演者 山口尚二郎（株式会社島津製作所） \\ 池 田 善 雄（株式会社日立メディコ） \\ 今 井 健 (東芝那須工場) \\ 森 定 義 (九州大学附属病院) \\ 中 西 省: 三（大渡大学附属病院） \\ 藤 間 英 雄 (埼玉がんセンター) \\ 上 野 晴 樹 (東京電機大学理学部経営工学科)
}

\section{1. $\mathrm{X}$ 線機械装置の機械的安全性について}

\author{
島津製作所 医用技術部
}

山口尚二郎

Key Words: Mechanical safety, Mechanical danger, Human engineering, Safety engineering

\section{MECHANICAL SAFETY OF MEDICAL X-RAY EQUIPMENT}

\section{By SHOJIRO YAMAGUCHI}

Medical Systems Div., Shimadzu Corporation

\section{Summary}

Medical X-ray equipment brings about radiological, electrical and mechanical dangers to the patient and the operator.

In order to produce the equipment free from danger, technical consideration especially from the standpoint of human engineering and safety engineering is necessary.

Fundamental methods used in the design of medical X-ray equipment and several concrete examples of these methods are introduced in this paper. 


\section{1.はじめに}

科学技術の進步・経済衤会の発達などにより，社会全 体の考え方が変化し，より高級で便利な装置が求められ るようになっている.

高級で便利な装置は，一般的に䓂って，新しい高度な 技術を使朋した複雑な装置であり，装置の信頼性・安全 坐がそこなわれがちな香のである。

さらに，医用X線機器は，禾ともと伦険要因の多いも のであるといわれている。すなわち，人休传畫なX線 を曝射し，X線発生のため高電生を用い，思者を垂せて 移動させ，重量物である誩断機器を蚛者に接近させるな

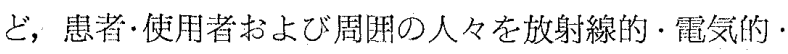
機械的な危険にさらす可能性がある (Fig. 1). IEC O掭 用電気機器安全通則においては，これらの危険に対する 防護は機器自体・唁療室に具備する設備および機器の使 用法のそれぞれに䂆防策を講じるととによりおとなうと している゙!

ここでは，X線機械装置を取り上げ，機械的安全を磪 保するために機器白体に諢じる予防策について，設計に 從事する者の場加ら検討をおこなう。

\section{2. 安全確保のために}

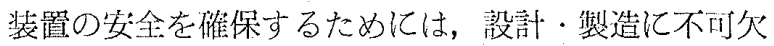
な機械工学・電気工学なよ゙の基本工学だけでなく，人間 て学・信頼性工学・㚣全性丁学なよ゙の面からのアプロー チが必要である2.

また，装置の設計・製造に当っては，Table 1 亿示す ように，国内法および JIS 規格などの安全事俱老满足さ

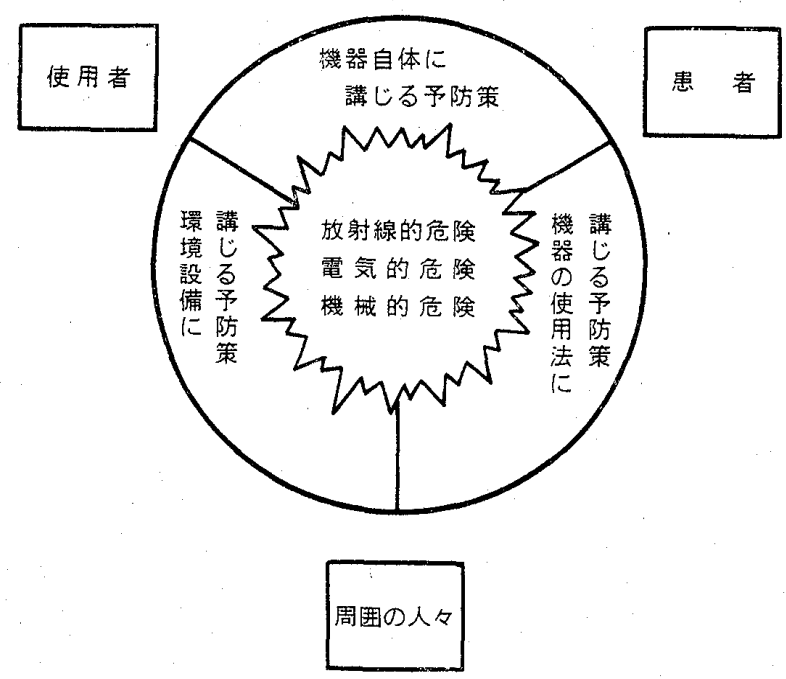

Fig. 1. Dangers caused by medical X-ray equipment and their protection methods.
Table 1. Laws and standards related to safety design of medical X-ray equipment.

医用X線装置の安全設䚵に関する法令・規格など

厚生省告示「医療用エックス線装置基準」

医療法施行規則

国 電離放射線障琱防生规則

䇰㗢安全街生法

内 医用電気機器の使用上（安全及び危険防止上）の 注意事項

JIS 規格など

ICRP Publication 15

外 IEC Publication 407

IEC Publication 601

国 HEW 規格

UL 規格など

せるだけでなく，ICRP・IEC などの 国際规格に対応さ せ, さらに危険防止に必要な手段を機器自体に組み込む 無条件安全を目標としなければならない。

設計・製造に従事する者は，安全性の高い装埴を提供 しなければならないという社会的責任を負っている，安 全に対する使命・責任を強く認識することが, 安全な装 置を作り出すための必須条件であるといえる。

\section{3. 人間工学的配慮}

装置の設計に当り，まずその機能・強度・加工性・経 済性などについて考虑がはらわれるのが普通である。し かし，たとえてれらが満足されても，使用者と装置すな わ方人間之機械の関係がうまく整合し，安全性・操作性 において優れたものでなければ，装置の機能を充分発揮 させたものとはいえず，使用者の作業能率の低下・症 労・事故を発生させることがある゙.

人間々機械之を一つの系之見なし，乙れを人間の持つ 生理・心理・形態・機能などの特性に基づき設計あるい は改暜しようとするのが人間工学の目的である.なお， 作業性・操作性・作業環境の改善も人間工学の課題であ るが，ここでは特に機械的安全について検討を加えるこ とにする。

\section{1 患者の特異性の考虑（親切設計）}

一般的な人間一機械系は，通常，装置と乙れを操作す る使用者により構成される。医用機器に执いては，乙れ ら以外使用者の指示掠よび装置加らの作用に一方的に 㮸うことが要求され，老人や子供であったり病気などの ため，正裳人としての反作用が期待できない㭧者がこの 


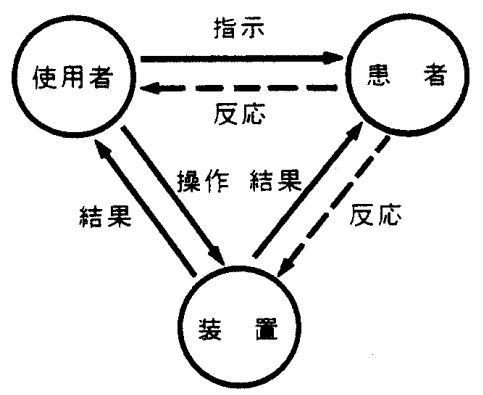

Fig. 2. Man-machine system in the field of medical equipment.

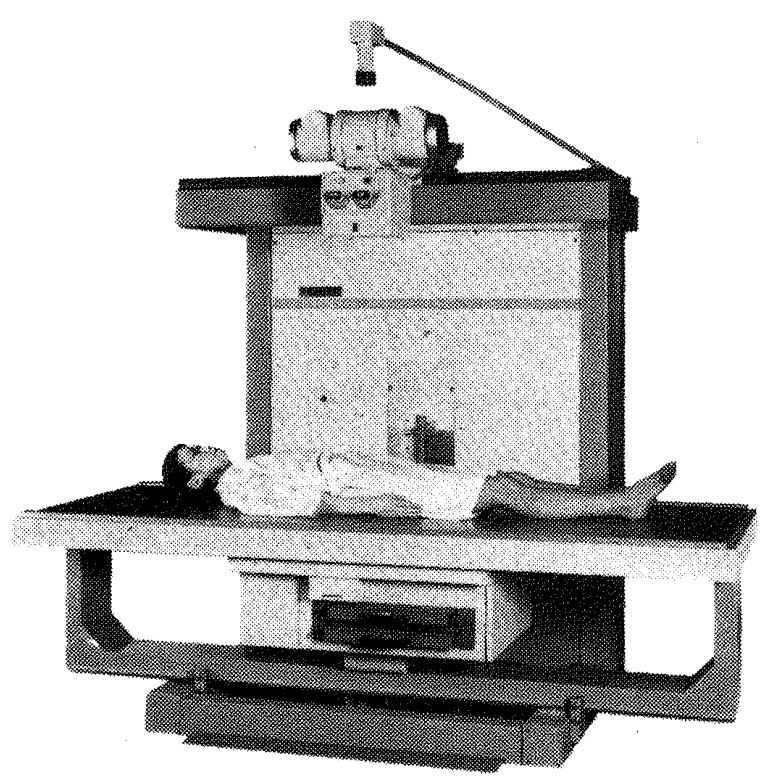

Fig. 3. Appearance of a newly-developed planigraphic device with cassetteless Bucky changer.

系の中に含まれる点で異なっている（Fig.2）。

装置の設計・製造に当っては，危険に対して舆防倩で ある患者の安全確保を特に重視し，患者の持つ特異性を 配慮した親切な設計をおこなう必要がある.

Fig. 3 は，新しく開発したカセッテレス断層撮影装置 の全景を示したものである.テーブル面を低くフラット にして患者の开降を容䀛にしたり，FFDを延長して界 降時の頭と可動絞りとの衝突を防止したり, 従来患者の 側方に露出して運動をおこなっていたX線管と撮影装置 の連結桿を装置に内藏させ，さらに裁断高さの指示方法 を指針式より光学式に政善するなよ゙, 従来の装狊におい て患者の周囲に存在した不安全要因を取除いた設計がお こなわれている.

胸部撮影装置や立位位置での透視撮影台において，ボ シショニングのために患者を上方へ電動移動させること は，転落事故を発生させる恐れがある．思者の体格に応
じて装啨側を移動させるものがより親切な装置といえ る.

\section{2 フールプルーフの採用}

人は, 元来感情に左右されやすく, 単調さにいらいら し，きやすく，疲学しやすいなどの特性を持ち，ケア レスミスを起すことがあるのはよく知られている，人が 犯す剖り，いわゆるヒューマンエラーは，一般に人間の 機能の不確かさと機械や環境などの要因が互いに関係し て生じると考えられている゙．

人は䛊りを犯すものであるという洘えに基ずき，使用 者が愦った操作をおこしにくく，あるいはおこなえない 機構を装置に取人れ，もし操作を誤まっても患者・使用 者の安全を確保するフールプルーフが採用される。

設計の段階において前もって予想できる事故に対して は防護策を蛮じ，事故の発生を末然に防止させるのはい うまでもないか，この段階では想定できなかった人的要 凡によるものと考えられる事故が発生する屯のである。

しの事故の原因を，使用者の不注意・訓練不足のためな よ゙としているだけでは何ら改善がおこなえなり，事故原 因を分析し，ヒューマンエラーを引起していた要因を拾 い上げ，これを除上するよう対策を溝じなければならな ().

Fig. 4 は，透視撮影台における患者压迫彰断の様子を 示している. 圧迫筒の駆動には必要最小限度の駆動力を 発生する小形モータを採用し，最大珀力を制限してい る. 压迫中にテーブル平面動をおこなっても，压迫筒は 白動後退して患者に損傷を与えるのを防止する.

透視撮影台におけるテーブルと林・天井との衝突を避

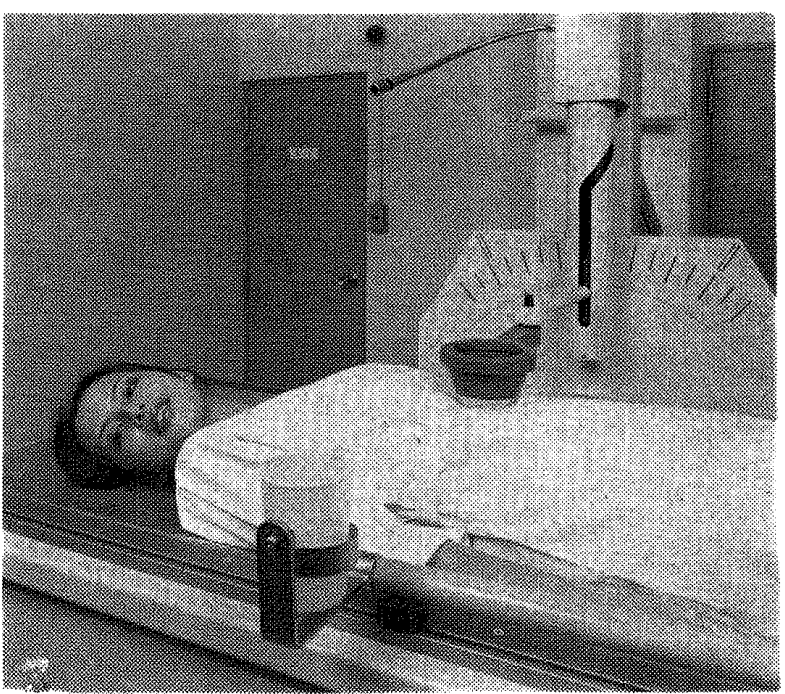

Fig. 4. Compression diagnosis with an X-ray diagnostic table. 


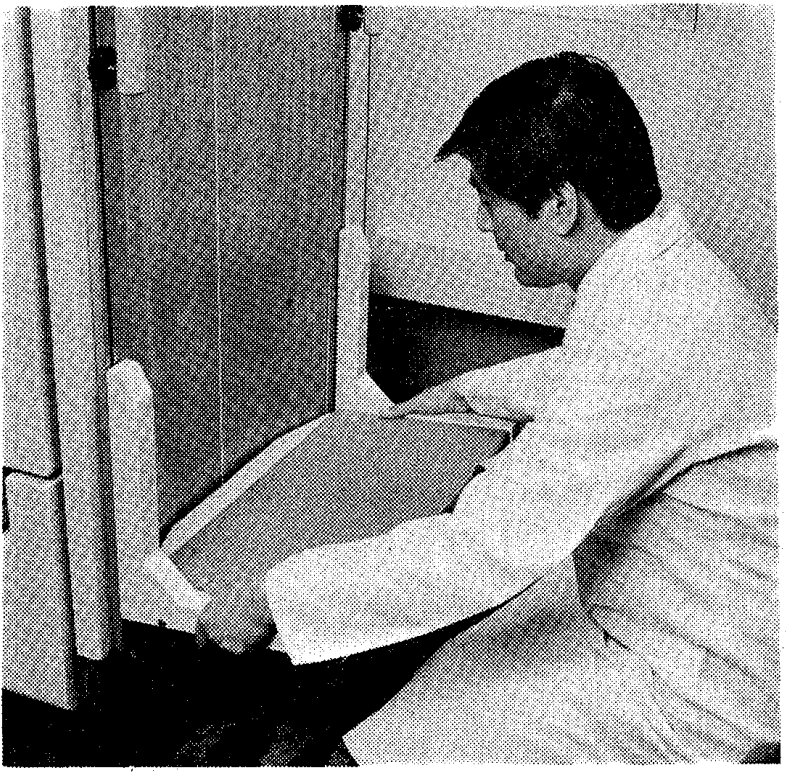

Fig. 5. Setting of a foot-rest.

けるためのテーブル自動引上げ機構・テーブル引医し機 構, テーブル倒動を水平位で一担停止させ，不要意な逆 傾斜位への移行を防ぐため別個の操作を要するようにし た工夫などがフールプルーフの例である.

\section{3 使用者の個人差排除}

男性・女性，力の強弱など使用者の特性にかかわらず 誰が操作をおこなっても同じ結果が得られるように考慮 する必要がある．これは一種のフールプルーフとも考え られる。

たとえば，透視撮影台に扔ける履当・踏台の固定では テーブル両側に設けられた $\mathrm{T}$ シゾレールの任意の位置に ネシにて固定する方法がとられている．しかし，乙の方 法では固定の仕方に個人差が発生し，締付力が不足する と滑り落ちることがある．Fig. 5 は，乙れを改善した踏 台の固定方法を示している，すなわち下面雨側にあるレ バ一を握って踏台を任意位置に移動させ，レバーから手 を離す之機械的にロックされ, 踏台にかかる荷重が増加 する程，てとの原理により固定力が増す方法が採用され ている.

\section{4 デッドマン形の採用}

㭧者に绝害を及ぼす恐れのある動力移動部分は，ハン ドル・スイッチに人が力を加えている間だけ移動し，そ の力を取去れば直ちに停止するデッドマン形制御回路を 採用して患者の安全を計る。

たとえば，透視撮影台におけるテーブル起倒動・平面 動・圧迫筒操作などのハンドルは，力を取去れば内蔵さ れたスプリング力により電気接続がオフになる中央位置 に復㴆し，移動加停此する。

\section{5 省力化・自動化}

装置の省力化・自動化を進めることは，作業の簡素化 が計れ，使用者が本来の謬断業務に注意力を集中できる ため疲労が減少するなど，間接的な装置の安全性向上に つなかると考えられる。

たとえば，撮影台・透視撮影台などのカセッテレス化， $\mathrm{X}$ 線照射野の大きさを必要最小限に制御する自動可動絞 り機構, 撮影部位・嬮さにかかわらず適正濃度のX線写 真が得られる自動露出機構は，使用者の作業能率を改善 させている。

\section{4. 信頼性工学的配慮}

\section{1 余裕設計}

装置の安全性・信頼性を確保するために，信頼性の高 い部品あるいは強度の大きい部品を使用したり，部品の あつ性能一杯に使用せず，余裕をもって控え目に使用し， 部品飞かかるストレスを緩和させる方法がとられる。と れらの方法は，安全性工学に批いてはディレーティング といわれ5，機械工学における安全率の考え方がこれに 相当する。

装置の設計に当って，人に危害を及ぼす恐れのある個 所苭るいは荷重の推定やストレスの算定に不確実なとと ろがあれば，これに対する危険度を補うために，設計応 力の側に安全率を考え，求められた応力に安全率を乗じ た応力を設計応力とし，実際の応力と設計応力の間に安 全余裕を設ける6)。

Table 2 は，機械設計に用いられる安全率を示したも のである6 。 たとえば，鋼材に衝撃的な引張荷重がかか

Table 2. Safety factors based on tensile strength 引張強さに対する安全率 (Unwinn)

\begin{tabular}{|c|c|c|c|}
\hline \multirow{2}{*}{ 材 } & \multirow{2}{*}{ 料 } & \multicolumn{2}{|c|}{ 安 全 } \\
\hline & & 静 荷 重 & 衝撃荷重 \\
\hline 鋳 & 鉄 & 4 & 15 \\
\hline & & 3 & 12 \\
\hline
\end{tabular}

Table 3. Relative equations for wire-rope and pulley.

ワイヤロープ及び滑事の関係式（JIS Z4703-1980）

$$
\begin{array}{ll}
\frac{D}{d} \geqq 300 & d: \text { ワイヤロープ素線径 } \\
\frac{D}{d r} \geqq 20 & d r: \text { ワイヤロープ直径 } \\
& D: \text { 滑車の有効直径 }
\end{array}
$$


る場合には，一般に12倍の安全余裕を設ける。

懸垂保持機構に使用される门イヤロープ・滑車に，

Table 3 亿示す関係式”を満足させ，静止安全率を10以 上としたり，X線機械装置において人体の安全体重を $135 \mathrm{~kg}$ とするのはこの考えに基づいている.

\section{2 几長設計}

同じような機能を 2 つ上多重に備えるととにより， 安全性・信頼性を高める設計方法，すなわち冗長設計が おこなわれる，多重に備えられた全てが故障するまでシ ステム全体の故障とならなりため，それだけ信頼性が堷 加古る.

たとえば，奬垂保持機構に落下防止機棈すなわち安全 装置を備けたり，2本のワイヤロープのそれぞれに独立 して重量物の懸垂をおこなわせる方法，いわゆるワイヤ ロープの 2 本吊りは，乙の考えに基づいている.

\section{3 フェイルセーフの採用}

人体に危害を及添す恐れのある個所には，余裕設計 . 圥長設阡などにより装置の安全性・信頼性を增す方法が 採用される.さらに，装置設計の立場から考えて，万一 故障が発生すると重大事故を引起す恐れがあると予測さ れる個所には，故障の場合で屯必ず安全側に働くようフ ェイルセーフを採用する。

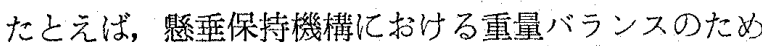
に用いられるばねには，引張ばねを用いず玨縮コイルば ねを採用する。これはばね破断時の懸重重量物の落下防 止を目的としたものである。．また，透視撮影台の正迫機 構において，停電時や故障時に容易に患者の圧迫を解放 できるようにしたり，テーブル起倒動・平面動の移動の 終端を検出し停止させるそットスイッチとは別に, 安全 スイッチや機械的ストッパを設けて安全を磪保してい る.

適切なフェイルセーフを採用するととは，たとえそれ が簡単な手段であっても，事故の発生を未然に防止す る。また，装置の保全・点検が容易な設計をおしなうと とで装䁂の損傷を発見しやすくし，事故の発生を末然に 防止するのも一種のフェイルセーフと考えられている.

\section{4 設計審查など}

装㽡の開発に直接関係しなかった專門家が，装置の機 能・信頼性・安全性・生产性・保全性などについて 検 討・審查をおこない，設計上の問題点の指摘・改善がお こなわれる。

裝造段階においては，装置の機能検查だけでなく，安 全性・信頼性審查を台めた品質管理が扣てなわれる。ま た，使用者との相互理解を深め，フィードバックされる 報告・意兒・要望を尊重し，装置の改善が㧍こなわれ る. 一方, 装置の安全確保を重要視するあまり, 余裕設 計・圥長耤計などを多用すれば，装置の重量・容積・コ ストが増大しマイナス面が発生する5)。とれらの間を最 適にバランスをとる技術的妥協（トレードオフ）も重要 である。

\section{5. おわりに}

医用X線装置の設計に從事する者の立場から，思者・ 使用者の機械的安全を確保するための基本的な考え方之 若干の具体例について報告した.

装置の安全性の大半は，設計の段階で決定されるとい われ，設計者の責任は重大である，安全な装置を提供す るという設計者に荷せられた使命を再認識し，人間工 学·安全性工学に基づき, 安全設計をさらに推進させる ことが重要であると考えている.

最後に，発表の機会を戴いた第37回総会役員およびシ ンポジウム関係者の皆様に感謝の意を表します。.

\section{文 : 献}

1) IEC 医用電気機器安全通則，コロナ社，ix, (1980).

2) 森山有相：彭断用X線機器の機械的安全性，日放技 学詰志, 33(4), 444, (1977).

3）稲田重男，他：機械設計ハンドブック，朝倉畫苫， 126, (1975)

4) 浅居囍代治：現代人間工学概論，才一么社， 80 , (1980).

5) 塩㫕 弘：信頼性工学入門，丸善，160，(1972).

6) 機械工学便覧，日本機械学会，4-27，(1965).

7) JIS Z4703-1980. 